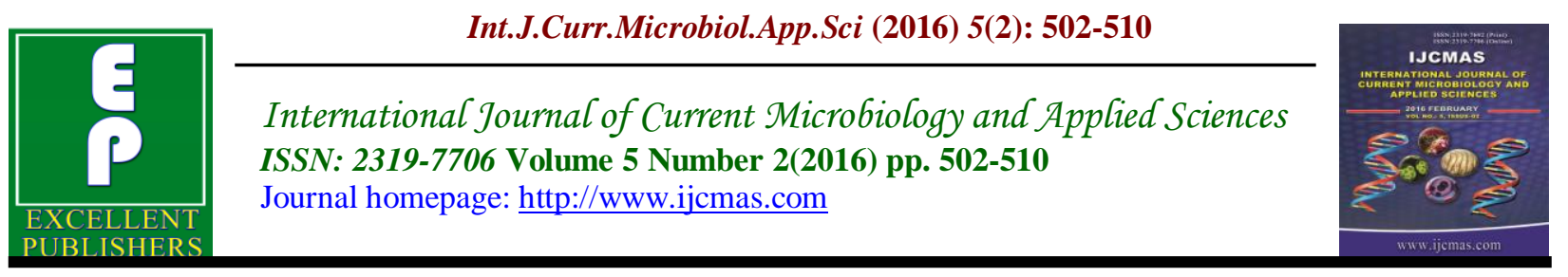

Original Research Article

doi: http://dx.doi.org/10.20546/ijcmas.2016.502.057

\title{
Callus Induction and Plant Regeneration from Leaf Explants of Apple (Pyrus malus L.) cv. Golden Delicious
}

\author{
Ravi Shekhar Kumar*, Charu Joshi and Tapan Kumar Nailwal \\ Plant Tissue Culture and Molecular Biology Laboratory, Department of Biotechnology, \\ Bhimtal-263136, Kumaun University, Nainital, Uttrakhand, India \\ *Corresponding author
}

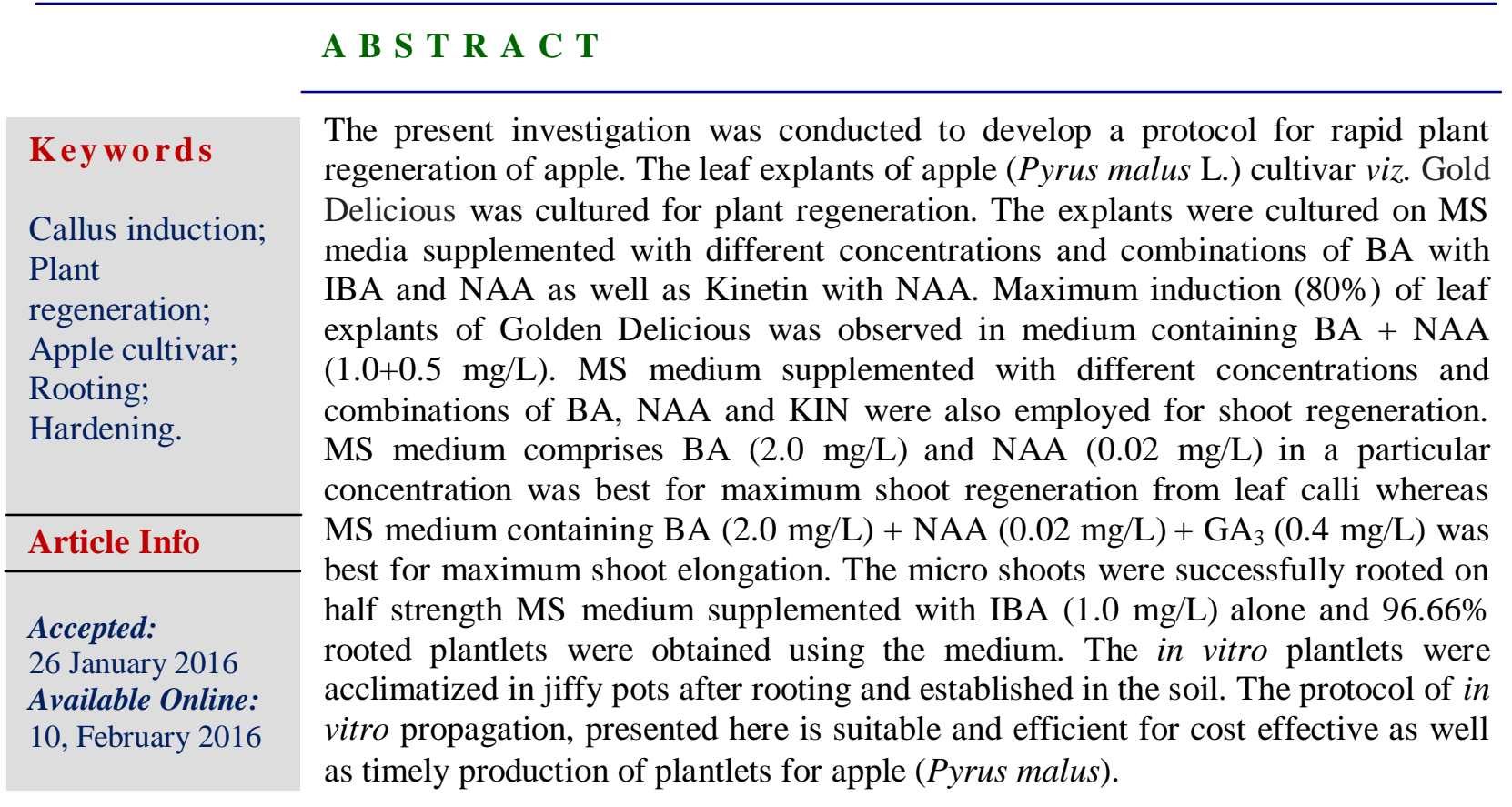

\section{Introduction}

Apple is a woody plant belonging to the family, Rosaceae (Brown, 1992). Apple is very nutritious, aromatic and delicious fruit and a rich source of vitamins $\mathrm{A}, \mathrm{B}$ and $\mathrm{C}$. It contains about $11 \%$ sugar besides essential minerals in amounts. Apples purify the blood by transforming toxic chemicals into less harmful compounds and thereby lower blood cholesterol and different free-radicals as well as beneficial to the lymphatic system (Sabir and Shah, 2004).
It can reduce the risk of prostate, colon and lung cancer and may protect the brain from neurodegenerative diseases (Dobrzanski et al., 2006). Apple fruit is very good source of important phytochemicals like antioxidants, flavonoids and other free phenolics which are not bound to other compounds (Boyer and Liu, 2004). These days, apples are growing all over the world. Apples are the second most important temperate fruit crop next to grapes and fourth among all fruit 
species following oranges, bananas and grapes regarding world fruit production (Jackson and Palmer, 1999).

Apple is conventionally propagated by vegetative methods, such as budding or grafting. Although these traditional propagation methods do not ensure diseasefree and healthy plants, they depend on the season; moreover, they typically result in low multiplication rates. Micropropagation of apple rootstocks has opened up new areas of research and fruit tree propagation allowing the problems of conventional methods to be overcome and enabling rapid multiplication of disease-free fruit plants at a commercial scale (Bahmani et al., 2009; Zimmerman and Debergh, 1991).

Tissue culture propagation is a method to produce own rooted plants because it has the potential for large scale increase of plants in short time. Clonal propagation through tissue culture called micropropagation can be achieved in a short time and space. Thus, it is possible to produce plants in large numbers starting from single individual (Razdan, 1993). Micropropagation is a widely known method for plant multiplication and has been extensively used for the rapid multiplication of many plant species along with Pyrus species (Lane, 1992). Mature woody plants are more difficult to propagate vegetatively (Druart, 2003) but different techniques were developed for their in vitro micropropagation (Sharma et al., 2000). In the present study, authors have developed an efficient plant regeneration protocol of Apple (Pyrus malus L.) cv. Gold Delicious from green leaf explants.

\section{Materials and Methods}

\section{Plant Materials and Explants Preparation}

Fresh young leaves of Apple (Pyrus malus
L.) cv. Gold delicious were obtained from CISH (Central institute of Subtropical Horticulture) Mukteshwar, Uttarakhand, India. The explants were washed thoroughly under running tap water for $5 \mathrm{~min}$, then immersed in water containing 3-5 drop of surfactant (Tween-20) for 5-10 min in gentle agitating condition and rinsed thoroughly. Leaves were treated with $0.5 \%$ fungicide (bavistine) solution for $20 \mathrm{~min}$ and were thoroughly washed with sterilized double distilled water under aseptic condition followed by $0.1 \%$ surface disinfectant (mercuric chloride, $\mathrm{HgCl}_{2}$ ) treatment for 5 min. Finally, leaves were washed with sterile double distilled water for 4-6 times. Water present on the surface of the leaves was dried out with the help of autoclaved filter papers.

\section{Culture Medium and Conditions}

The MS cultured medium (Murashige and Skoog, 1962) was used with 3\% (w/v) Sucrose (Hi-media, Mumbai, IN). The medium was supplemented with different concentrations and combinations of $\mathrm{N}^{6-}$ benzyladenine (BA), Kinetin (Kn), Indole butyric acid (IBA) and $\alpha$-napthelene acetic acid (NAA) (Hi-media, Mumbai, IN). The $\mathrm{pH}$ of medium was adjusted to 5.8 prior to gelling it with $0.3 \%(\mathrm{w} / \mathrm{v})$ CleriGel (Himedia, Mumbai, IN). All the media culture bottles containing $50 \mathrm{ml}$ MS media were autoclaved at $15 \mathrm{lbs}$ for $20 \mathrm{~min}$ at liquid cycles.

\section{Shoot Induction from Leaf Derived Callus}

Sterile leaves were cut into $5 \times 5 \mathrm{~mm}$ pieces and inoculated aseptically in culture bottles containing $50 \mathrm{ml}$ MS media supplemented with various PGRs like BA (0.5-1.25 mg/L), NAA (0.4-1.25 mg/L), IBA (0.0-0.5 mg/L), and Kinetin (1.0-2.0 mg/L) in combinations (Table 1) for callus induction. Sub-culturing 
was done in fresh medium at regular intervals for continuous growth. Data were recorded after 40 days of inoculation. For shoot induction from leaf derived callus, 45 days old callus was transferred to MS medium containing $\mathrm{BA}(0.75-3.0 \mathrm{mg} / \mathrm{L})$, NAA (0.01-0.03 mg/L) and Kinetin (1.0-3.0 $\mathrm{mg} / \mathrm{L})$ in different combinations and concentrations (Table 2).

\section{Shoot Multiplication and Elongation}

The microshoots derived from callus were further used for multiplication and elongation so they were inoculated on MS medium having $\mathrm{GA}_{3}(0.03-0.04 \mathrm{mg} / \mathrm{L}), \mathrm{BA}$ (1.0-3.0 mg/L), NAA (0.01-0.04 mg/L) and Kinetin (1.0-3.0 $\mathrm{mg} / \mathrm{L})$ in different combination and concentrations (Table 3 ).

\section{Root Induction and Acclimatization}

Elongated shoots with 6-7 leaves $(>5 \mathrm{~cm}$ in length) were excised in vitro from all treatments and were transferred to halfstrength MS medium with $2 \%$ sucrose $(\mathrm{pH}$ 5.8) and various concentrations of IBA (0.5$2.5 \mathrm{mg} / \mathrm{L}$ ) (Table 4) in combination and incubated for overnight. Later, the treated shoots were grown on PGR free halfstrength MS medium. Each treatment was replicated 5 times using single plantlet for each treatment. After 6 weeks of root induction plantlets were taken out from culture bottle and gently washed under running water. They were potted in thermacol cups $(8 \times 12 \mathrm{~cm})$ containing sterile soil and farmyard manure (3:1), covered with plastic bags having small holes to maintain humidity and finally placed inside culture room at $25 \pm 2{ }^{\circ} \mathrm{C}$ (16 hours photoperiod). After 15 days, covers were removed, maintained as such for 3 weeks and then transferred into earthen pots $(15 \times$ $20 \mathrm{~cm}$ ) and kept inside greenhouse for further growth (Figure 1). Well hardened plants were taken out to the direct sunlight. Data for per cent rooting, average number of roots per shoot, average root length and average length of longest root were recorded after 6 weeks of inoculation in PGR-free half strength MS medium.

\section{Results and Discussion}

\section{Shoot Induction from Callus}

The response of leaf explants to various concentrations and combination of BA, IBA, NAA and Kinetin in MS culture medium was studied. The regeneration frequency of callus was the highest (86.66\%) on MS solid culture medium supplemented with 1.0 $\mathrm{mg} / \mathrm{L} \mathrm{BA}$ and $0.5 \mathrm{mg} / \mathrm{L}$ NAA (Table 1). The highest frequency was observed when leaves were cut-wounded and placed with the abaxial surface in contact with the medium. The results were nearly 3 -fold better when leaves were cut instead of crushing.

The effect of the callus on MS solid culture medium supplemented with BA $(2.0 \mathrm{mg} / \mathrm{L})$ and NAA $(0.02 \mathrm{mg} / \mathrm{L})$ was also studied. The results showed that the highest regeneration frequency of shoot induction $(85.90 \%)$ and the maximum number of shoots (8.0) were obtained when callus were placed horizontally in contact with the medium (Table 2).

\section{Shoot Multiplication and Elongation}

When shoots, excised from multiple shoot cultures, were placed vertically, multiplication was seen in all the combinations tested (Table 3). Highest multiplication and elongation rate (20-fold) with $9-10 \mathrm{~cm}$ long shoots was obtained on medium having $0.04 \mathrm{mg} / \mathrm{L} \mathrm{GA}_{3}, 2.0 \mathrm{mg} / \mathrm{L}$ BA, and $0.02 \mathrm{mg} / \mathrm{L} \mathrm{NAA} \mathrm{(Figure} \mathrm{1).} \mathrm{From}$ each explant 12-13 shoots were obtained on $1.5 \mathrm{mg} / \mathrm{L} \mathrm{BA}, 0.01 \mathrm{mg} / \mathrm{L} \mathrm{NAA}$, and 0.03 
$\mathrm{mg} / \mathrm{L} \mathrm{GA}_{3}$, where some shoots was vitrified. Multiplication rate of 15 -fold and longer shoots were achieved when $2.5 \mathrm{mg} / \mathrm{L} \mathrm{BA}$ with $0.02 \mathrm{mg} / \mathrm{L} \mathrm{NAA}$, and $0.04 \mathrm{mg} / \mathrm{L} \mathrm{GA}_{3}$. The combinations of $0.03 \mathrm{mg} / \mathrm{L} \mathrm{GA}_{3}, 1.0$ $\mathrm{mg} / \mathrm{L} \mathrm{Kn}$, and $0.01 \mathrm{mg} / \mathrm{L}$ NAA didn't showed any increase in multiplication and elongation of shoots.

\section{Root Induction and Hardening}

Roots were observed from regenerated shoots after 5 weeks of in vitro culture. The percentage of in vitro shoots that rooted varied significantly according to the IBA concentration of the medium, with the best rooting $(96.66 \%)$ obtained with $1.0 \mathrm{mg} / \mathrm{L}$ IBA (Table 4). In the present study IBA (1.0 $\mathrm{mg} / \mathrm{L}$ ) was effective for induction of roots.
In this concentration, the roots reached maximum length of $10.0 \pm 0.57 \mathrm{~cm}$ within three weeks of culture (Figure 1). The increased root length leads to increase in the survival percentage of hardened and field grown plants. As the concentration of IBA increased the percentage of rooting was decreasing. The highest numbers of roots (Figure 1) were obtained on the MS half medium supplemented with $1.0 \mathrm{mg} / \mathrm{L}$ IBA. After three weeks, rooted plantlets were transferred into plastic pots containing autoclaved sand and soil (3:1) mixture and were maintained in the culture room for two weeks (Figure 1). They were then transferred to shade and ultimately to field conditions. The survival rate of plantlets was $80 \pm 5 \%$ in the field.

Table.1 Effect of Different Combinations of Ba, Naa And Kinetin on Callus Induction of Apple (Golden Delicious) on Ms Solid Medium

\begin{tabular}{|c|c|c|}
\hline PGR conc. $(\mathrm{mg} / \mathrm{L})$ & Days required for response & \% of Response \\
\hline $\mathrm{BA}+\mathrm{NAA}+(0.0+0.0)$ & $0.000 \pm 0.000^{\mathrm{a}}$ & $0.000 \pm 0.000^{\mathrm{a}}$ \\
\hline $\mathrm{BA}+\mathrm{NAA}+(0.5+0.4)$ & $0.000 \pm 0.000^{\mathrm{a}}$ & $0.000 \pm 0.000^{\mathrm{a}}$ \\
\hline $\mathrm{BA}+\mathrm{NAA}+(\mathbf{1 . 0}+0.5)$ & $6.000 \pm 0.577^{b}$ & $86.667 \pm 3.333^{e}$ \\
\hline $\mathrm{BA}+\mathrm{NAA}+(1.0+0.75)$ & $10.333 \pm 1.453^{\text {cde }}$ & $70.000 \pm 5.774^{\mathrm{cd}}$ \\
\hline $\mathrm{BA}+\mathrm{NAA}+(1.5+1.0)$ & $11.000 \pm 2.082^{\mathrm{def}}$ & $43.333 \pm 8.819^{b}$ \\
\hline $\mathrm{BA}+\mathrm{IBA}(0.75+0.5)$ & $21.667 \pm 0.882^{h}$ & $73.333 \pm 3.333^{\text {cde }}$ \\
\hline $\mathrm{BA}+\mathrm{IBA}+(1.0+0.5)$ & $6.333 \pm 0.333^{b}$ & $76.667 \pm 3.333^{\mathrm{de}}$ \\
\hline $\mathrm{BA}+\mathrm{IBA}(1.25+0.5)$ & $8.000 \pm 0.577^{b c}$ & $66.667 \pm 8.819^{\mathrm{cd}}$ \\
\hline $\mathrm{Kn}+\mathrm{NAA}+(1.0+0.75)$ & $13.667 \pm 0.882^{\mathrm{fg}}$ & $63.333 \pm 6.667^{\mathrm{cd}}$ \\
\hline $\mathrm{Kn}+\mathrm{NAA}+(1.25+0.75)$ & $9.333 \pm 0.333^{\mathrm{cd}}$ & $70.000 \pm 5.774^{\mathrm{cd}}$ \\
\hline $\mathrm{Kn}+\mathrm{NAA}+(1.5+0.75)$ & $11.333 \pm 0.882^{\mathrm{def}}$ & $60.000 \pm 0.000^{\mathrm{c}}$ \\
\hline $\mathrm{Kn}+\mathrm{NAA}+(1.5+1.0)$ & $12.667 \pm 0.882^{\mathrm{efg}}$ & $66.667 \pm 3.333^{\mathrm{cd}}$ \\
\hline $\mathrm{Kn}+\mathrm{NAA}+(2.0+1.0)$ & $15.000 \pm 0.577^{\mathrm{g}}$ & $63.333 \pm 3.333^{\mathrm{cd}}$ \\
\hline $\mathrm{Kn}+\mathrm{NAA}+(2.0+1.25)$ & $24.000 \pm 0.577^{\mathrm{h}}$ & $43.333 \pm 3.333^{b}$ \\
\hline \multicolumn{3}{|c|}{$\begin{array}{l}\text { Note: The values represent the means }( \pm \mathrm{SE}) \text { of three independent experiments. Mean } \\
\text { values within a column followed by the same letter are not significantly different by } \\
\text { Duncan's multiple range test }(\mathrm{P}<0.05) \text {. }\end{array}$} \\
\hline
\end{tabular}


Table.2 Effect of Different Combinations of Ba, Naa And Kinetin on Shoot Induction from Leaf Derived Calli of Apple (Golden Delicious) on Ms Solid Medium

\begin{tabular}{|c|c|c|c|}
\hline PGR conc. $(\mathrm{mg} / \mathrm{L})$ & $\begin{array}{ll}\begin{array}{l}\text { Average } \\
\text { of shoots }\end{array} & \\
\end{array}$ & $\begin{array}{l}\text { Mean Average } \\
\text { shoot length }(\mathrm{cm})\end{array}$ & $\begin{array}{l}\text { Average number } \\
\text { of leaves }\end{array}$ \\
\hline MS Full BA+NAA $(0.0+0.0)$ & $0.000 \pm 0.000^{\mathrm{a}}$ & $0.000 \pm 0.000^{\mathrm{a}}$ & $0.000 \pm 0.000^{\mathrm{a}}$ \\
\hline 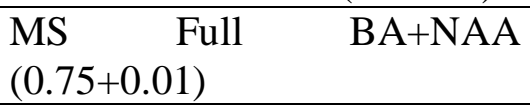 & $1.000 \pm 0.577^{\mathrm{a}}$ & $2.333 \pm 1.202^{b}$ & $5.667 \pm 3.480^{\mathrm{a}}$ \\
\hline MS Full BA+NAA $(1.0+0.01)$ & $2.667 \pm 0.333^{b}$ & $4.333 \pm 0.333^{\mathrm{bc}}$ & $18.333 \pm 2.667^{b}$ \\
\hline MS Full BA+NAA $(1.5+0.01)$ & $6.333 \pm 0.333^{\mathrm{de}}$ & $7.000 \pm 0.577^{\mathrm{de}}$ & $40.000 \pm 4.509^{d}$ \\
\hline $\begin{array}{l}\text { MS Full } \\
(2.0 .+0.02)\end{array}$ & $8.000 \pm 0.577^{\mathrm{e}}$ & $8.667 \pm 0.882^{e}$ & $57.333 \pm 5.239^{\mathrm{e}}$ \\
\hline MS Full BA+NAA $(2.5+0.03)$ & $3.667 \pm 1.202^{b c}$ & $6.000 \pm 0.577^{\mathrm{cd}}$ & $18.000 \pm 5.508^{b}$ \\
\hline MS Full BA+NAA $(3.0+0.03)$ & $3.667 \pm 0.667^{b c}$ & $5.667 \pm 0.882^{\mathrm{cd}}$ & $16.333 \pm 2.028^{b}$ \\
\hline MS Full Kn+NAA $(1.0+0.01)$ & $5.333 \pm 0.333^{\mathrm{cd}}$ & $6.667 \pm 0.667^{\text {cde }}$ & $24.333 \pm 2.848^{\mathrm{bc}}$ \\
\hline MS Full Kn+NAA (1.5+0.02) & $6.000 \pm 0.577^{d}$ & $5.000 \pm 0.577^{\mathrm{cd}}$ & $29.667 \pm 2.848^{\mathrm{c}}$ \\
\hline MS Full Kn+NAA $(2.0+0.02)$ & $6.333 \pm 0.333^{\mathrm{de}}$ & $5.333 \pm 0.882^{\mathrm{cd}}$ & $25.333 \pm 1.764^{b c}$ \\
\hline MS Full Kn+NAA $(2.5+0.02)$ & $6.333 \pm 0.667^{\mathrm{de}}$ & $4.333 \pm 0.882^{\mathrm{bc}}$ & $24.333 \pm 1.667^{b c}$ \\
\hline MS Full Kn+NAA (3.0+0.02) & $5.333 \pm 0.333^{\mathrm{cd}}$ & $5.667 \pm 0.667^{\mathrm{cd}}$ & $25.333 \pm 1.333^{b c}$ \\
\hline \multicolumn{4}{|c|}{$\begin{array}{l}\text { Note: The values represent the means }( \pm \mathrm{SE}) \text { of three independent experiments. Mean } \\
\text { values within a column followed by the same letter are not significantly different by } \\
\text { Duncan's multiple range test }(\mathrm{P}<0.05) \text {. }\end{array}$} \\
\hline
\end{tabular}

Table.3 Effect of Different Combinations of Ba, Naa And Ga3 on Shoot Multiplication and Elongation of Apple (Golden Delicious) on Ms Solid Medium

\begin{tabular}{|c|c|c|c|}
\hline PGR conc. $(\mathrm{mg} / \mathrm{L})$ & $\begin{array}{l}\text { Average no. of } \\
\text { shoots }\end{array}$ & $\begin{array}{l}\text { Average shoot } \\
\text { length }(\mathrm{cm})\end{array}$ & $\begin{array}{l}\text { Average number } \\
\text { of leaves }\end{array}$ \\
\hline $\mathrm{BA}+\mathrm{NAA}++\mathrm{GA}_{3}(0.0+0.0+0.0)$ & $0.000 \pm 0.000^{\mathrm{a}}$ & $0.000 \pm 0.000^{\mathrm{a}}$ & $0.000 \pm 0.000^{\mathrm{a}}$ \\
\hline $\mathrm{BA}+\mathrm{NAA}+\mathrm{GA}_{3}(1.0+0.01+0.03)$ & $6.667 \pm 0.333^{b}$ & $6.333 \pm 0.333^{b c}$ & $60.000 \pm 1.732^{b}$ \\
\hline $\mathrm{BA}+\mathrm{NAA}+\mathrm{GA}_{3}(1.5+0.01+0.03)$ & $14.333 \pm 1.202^{\mathrm{d}}$ & $7.333 \pm 0.333^{c}$ & $106.667 \pm 8.819^{d}$ \\
\hline $\mathrm{BA}+\mathrm{NAA}+\mathrm{GA}_{3}(2.0+0.02+0.04)$ & $19.667 \pm 0.882^{\mathrm{e}}$ & $9.000 \pm 0.577^{d}$ & $139.333 \pm 1.764^{\mathrm{e}}$ \\
\hline $\mathrm{BA}+\mathrm{NAA}+\mathrm{GA}_{3}(2.5+0.02+0.04)$ & $14.667 \pm 0.882^{\mathrm{d}}$ & $6.333 \pm 0.333^{b c}$ & $116.667 \pm 9.955^{\mathrm{d}}$ \\
\hline $\mathrm{BA}+\mathrm{NAA}+\mathrm{GA}_{3}(3.0+0.03+0.04)$ & $8.333 \pm 0.882^{b c}$ & $5.333 \pm 0.333^{b}$ & $70.667 \pm 4.702^{b c}$ \\
\hline $\mathrm{Kn}+\mathrm{NAA}+\mathrm{GA} 3(1.0+0.01+0.03)$ & $10.000 \pm 1.155^{\mathrm{c}}$ & $5.333 \pm 0.667^{b}$ & $84.000 \pm 3.055^{\mathrm{c}}$ \\
\hline $\mathrm{Kn}+\mathrm{NAA}+\mathrm{GA} 3(1.5 .0+0.01+0.03)$ & $8.667 \pm 0.882^{b c}$ & $5.000 \pm 0.577^{b}$ & $68.667 \pm 2.963^{b c}$ \\
\hline $\mathrm{Kn}+\mathrm{NAA}+\mathrm{GA} 3(2.0+0.02+0.03)$ & $9.667 \pm 0.333^{c}$ & $6.667 \pm 0.333^{b c}$ & $65.000 \pm 2.887^{b}$ \\
\hline $\mathrm{Kn}+\mathrm{NAA}+\mathrm{GA} 3(3.0+0.04+0.04)$ & $7.667 \pm 0.333^{b c}$ & $6.000 \pm 1.155^{\mathrm{bc}}$ & $69.667 \pm 2.603^{b c}$ \\
\hline
\end{tabular}


Table.4 Effect of Iba on Root Regeneration of Apple (Golden Delicious) on Ms Solid Medium.

\begin{tabular}{|c|c|c|c|}
\hline PGR conc. $(\mathrm{mg} / \mathrm{L})$ & Average no. of root & $\begin{array}{l}\text { Average root } \\
\text { length }(\mathrm{cm})\end{array}$ & \% of Response \\
\hline MS Full IBA(0.0) & $0.000 \pm 0.000^{\mathrm{a}}$ & $0.000 \pm 0.000^{\mathrm{a}}$ & $0.000 \pm 0.000^{\mathrm{a}}$ \\
\hline MS Full IBA (0.5) & $4.667 \pm 0.333^{b c d}$ & $5.000 \pm 0.577^{\mathrm{bc}}$ & $43.333 \pm 3.333^{c}$ \\
\hline MS Full IBA(1.0) & $6.000 \pm 0.577^{\mathrm{de}}$ & $4.333 \pm 0.333^{b}$ & $66.667 \pm 3.333^{\mathrm{de}}$ \\
\hline MS Full IBA (1.5) & $3.667 \pm 0.333^{b}$ & $5.333 \pm 0.667^{\mathrm{bcd}}$ & $66.667 \pm 3.333^{\mathrm{e}}$ \\
\hline MS Full IBA(2.0) & $5.667 \pm 0.333^{\text {cde }}$ & $4.667 \pm 0.667^{b}$ & $33.333 \pm 3.333^{b}$ \\
\hline MS Half IBA(0.5) & $8.333 \pm 0.882^{g}$ & $6.667 \pm 0.333^{\mathrm{d}}$ & $83.333 \pm 3.333^{f}$ \\
\hline MS Half IBA(1.0) & $11.000 \pm 0.577^{\mathrm{h}}$ & $10.000 \pm 0.577^{\mathrm{e}}$ & $96.667 \pm 3.333^{\mathrm{g}}$ \\
\hline MS Half IBA(1.5) & $8.000 \pm 0.577^{\mathrm{fg}}$ & $6.333 \pm 0.333^{\mathrm{cd}}$ & $83.333 \pm 3.333^{\mathrm{f}}$ \\
\hline MS Half IBA(2.0) & $6.667 \pm 0.333^{\text {ef }}$ & $4.333 \pm 0.333^{b}$ & $53.333 \pm 3.333^{d}$ \\
\hline MS Half IBA(2.5) & $4.333 \pm 0.333^{b c}$ & $5.000 \pm 0.577^{\mathrm{bc}}$ & $46.667 \pm 3.333^{\mathrm{cd}}$ \\
\hline \multicolumn{4}{|c|}{$\begin{array}{l}\text { Note: The values represent the means }( \pm \mathrm{SE}) \text { of three independent experiments. At least } 24 \\
\text { cultures were raised for each experiment. Mean values within a column followed by the same } \\
\text { letter are not significantly different by Duncan's multiple range test }(\mathrm{P}<0.05) \text {. }\end{array}$} \\
\hline
\end{tabular}

Figure.1 A. Initiation of Callus with $1.0 \mathrm{mg} / 1 \mathrm{ba}+0.5 \mathrm{mg} / \mathrm{l} \mathrm{naa}$; b. Shoot Proliferation from 45 Days Old Callus in ms Medium Supplemented with $2.0 \mathrm{mg} / 1 \mathrm{ba}+0.02 \mathrm{mg} / \mathrm{l} \mathrm{naa}$; c. Shoot

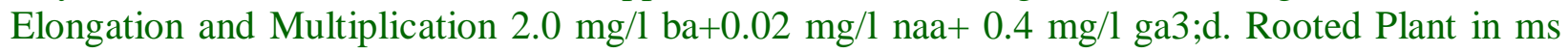
Half Medium Supplemented with $1 \mathrm{mg} / 1$ Indole-3 Butyric Acid (iba); e. Rooted Plant (35 days old);f. Hardened Plants in Greenhouse

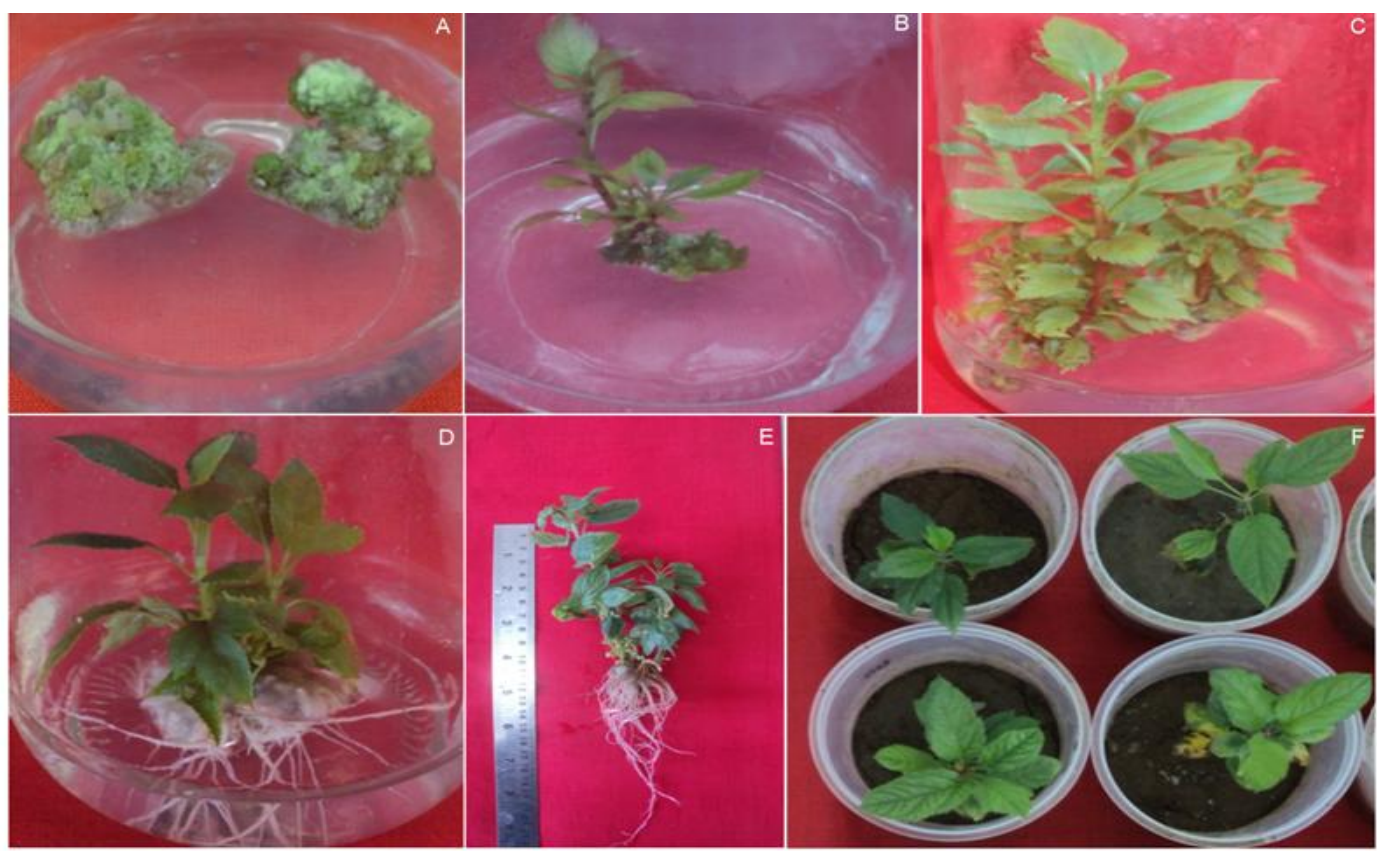


For callus induction, NAA (0.4-1.0 mg/L) in combination with $\mathrm{BA}(0.5-1.25 \mathrm{mg} / \mathrm{L})$ was employed. NAA and 2, 4-D are commonly used with BA for callus induction in various systems (Dhar and Joshi, 2005; Maheshwari and Kumar, 2006). Well-developed shoots were rooted on half MS medium fortified with two auxins (IBA and NAA; 2-8 mg/L). IBA supplemented medium exhibited superior rooting than NAA. IBA is considered as the most effective growth regulator for induction of roots in legumes (Ozean et al., 1992). IBA stimulated rooting was observed in Vigna radiata (Husan and Siddquai, 2006), Aegle marmelos (Nayak et al., 2007), Clitoria ternatea (Barik et al., 2007) and Cotinus coggygria (Metivier et al., 2007). During root induction, IBA treatment alone showed superior response for induction of roots. Similar to our reports, influence of IBA in root induction has been reported for several plants including Hemidesmus indicus (Sreekumar et al., 2000) and Cunila galiodes (Fracaro and Echeverrigary, 2001).

Various studies were conducted to develop protocols for efficient micropropagation and regeneration of apple cultivars. Al-Maarri et al (1994) indicated that Pyrus communis cultivars established best on medium containing $2.0 \mathrm{mg} / \mathrm{L} \mathrm{BAP,} 0.1 \mathrm{mg} / \mathrm{L} \mathrm{BA}$ and $0.2 \mathrm{mg} / \mathrm{L} \mathrm{GA}_{3}$. Somatic embryos were produced from leaf explants of Golden Delicious cultured on MS media with $\mathrm{B}_{5}$ $10.0 \mathrm{mg} / \mathrm{L} \mathrm{BA}$ and $3.0 \mathrm{mg} / \mathrm{L} \mathrm{NAA}$ in the dark (Liu et al., 1983). Compton and Gray (1993) observed that addition of IAA to the medium with BA increased callus formation. Lane (1982) reported that BA at concentration of $0.87 \mathrm{mg} / \mathrm{L}$ was required for establishment of shoot meristems of Macspur and Harrold and Red apple. During studies Belaizi et al (1989) depicted that $0.085 \mathrm{mg} / \mathrm{L}$ IBA and $0.035 \mathrm{mg} / \mathrm{L} \mathrm{BA}$ gave better results for establishment during preliminary growth phase for apical buds. Regeneration of adventitious shoots has been obtained from in vitro leaves of apple cultivars with vitamins, BA and IBA (Fasolo et al., 1990). However, BAP $0.77 \mathrm{mg} / \mathrm{L}$ in combination with the TIBA $0.17 \mathrm{mg} / \mathrm{L}$ gave the highest percentage of regeneration (Belaizi et al., 1990).

In conclusion, the present protocol is efficient and simple for in vitro adventitious shoot multiplication from callus cultures, and whole plant regeneration of Apple (Pyrus malus L.). Plant regeneration protocol can be potentially utilized for $e x$ situ conservation and mass propagation of Apple (Pyrus malus L.) The protocol was standardised by some manipulations of different PGRs, amino acids and carbohydrates for enhanced multiplication. Clones to meet the growing demand of energy plantations as well as need of food industry for food purpose. Future studies will focus on comparison between in vitro grown and field-grown plants in terms of their seed. Protocol explained in this research paper provides a rapid plant regeneration system which could be used for the soma clonal variation induction.

\section{Abbreviation}

Kn, Kinetin; MS, Murashige $\mathrm{T} \&$ Skoog F (1962); BA, 6-Benzyladenine; NAA, $\alpha$ Naphthalene-acetic acid; $\mathrm{GA}_{3}$, Gibberilic acid.

\section{Acknowledgement}

The authors are obliged to University Grants Commission (UGC), Govt. Of India, New Delhi for financial assistance in the form of project funding (Project File No. 41537/2012(SR) dated 17-07-2012). We are also thankful to Department of Biotechnology, Bhimtal-263136, Kumaun 
University, Nainital, Uttarakhand, India for providing laboratory facilities to carry out the research work.

\section{References}

Al-Maarri, K., Y. Arnaud and Miginiac, E. 1994. Micropropagation of Pyrus communis cultivar "Passe Crassane" seedlings and cultivar "Williams": factors affecting root formation in vitro and ex vitro. Scientia Horticulturae. 58, 207-214.

Bahmani, R., O. Karami and Gholami, M. 2009. Influence of carbon sources and their concentrations on rooting and hyperhydricity of apple rootstock MM106. World Applied Sciences Journal. 6(11), 1513-1517.

Barik, D.P., S.K. Naik, A. Mudgal and Chand, P.K. 2007. Rapid plant regeneration through in vitro axillary shoot proliferation of butterfly pea (Clitoria ternatea L.)-a twinning legume. In Vitro Cellular \& Developmental Biology. 43, 144-148.

Belaizi, M., H. Paul, R.S. Sangwan and Sangwan-Norreel, B.S. 1990. Direct organogenesis from intermodal segments of in vitro grown shoots of Apple Cv. Gloden Delicious. Plant Cell Reports. 9(9), 471-474.

Belaizi, M., R.S. Sangwan, A. David and Sangwan-Norreel, B.S. 1989. Control of stages in the micro propagation of apple (Pyrus malus L.) cv. Golden Delicious. Bulletin de la Societe Botanique de France, Letter Botaniques. 136(3), 187-197.

Boyer, J., and Liu, H.R., 2004. Apple phytochemicals and their health benefits. Nutrition Journal. 3(5), 1-15.

Brown, S. 1992. Genetics of apple. Plant Breeding Reviews. 9, 333-366.

Compton M.E. and Gray D.J. 1993. Shoot Organogenesis and Plant Regeneration from Cotyledons of Diploid, Triploid, and Tetraploid Watermelon. Journal of the American Society for Horticultural Science. 118(1), 151-157.

Dhar, U. and Joshi, M. 2005. Efficient plant regeneration protocol through callus for Saussurea obvallata (DC.) Edgew. (Asteraceae): Effect of explant type, age and plant growth regulators. Plant Cell Reports. 24, 195-200.

Dobrzanski, B., J. Rabcewicz and Rybczynski, R. 2006. Handling of apple transport techniques and efficiency vibration, damage and bruising texture, firmness and quality. $1^{\text {st }}$ ed. Dobrzanski Institute of Agrophysics. Polish Academy of Sciences, Poland.

Druart, P. 2003. Micropropagation of apples (Malus sp.). In: Mohan, J.S. and Ishii, K., (Ed.), Kluwer Academic Publishers, Dordrecht, The Netherlands, pp. 433-465.

Evaldson, I. 1985. Induction, growth and differentiation of callus stem segments of in vitro cultured apple shoots (Malus domestica Borkh). Swedish Journal of Agricultural Research. 15(3), 119-122.

Fasolo, F., F. Malovasi and Predieri, S. 1990. Cultivar dependent responses to regeneration in apple. Acta Horticulturae. 280, 61-63.

Fracaro, F. and Echeverrigaray, S. 2001. Micropropagation of Cunila galioides, a popular medicinal plant of south brazil. Plant Cell, Tissue and Organ Culture. 64, 1-4.

Husan, S.A.H. and Siddquai, S.A. 2006. Studies on morphogenetic potentials of stem explants of Vigna radiata (L.) Wilczek. Bulletin of Pure and Applied Science. 19, 73-75.

Jackson, D. and Palmer, D. 1999. Pome fruits. In: Jackson, D.I. and Looney, N.E. (Ed) Temperate and Subtropical 
Fruit Production., Second ed. CABI Publishing, Wallingford, pp. 189-197.

Lane, W.D. 1982. Plant manipulation in vitro with hormones [Linum usitatissimum, flax, Malus, apples]. Combined proceedings - International Plant Propagators' Society (Journal). 1, 101-108.

Lane, W.D. 1992. Micropropagation of apple (Malus domestica Barkh). In: Bajaj, Y.P.S. (Ed.). Biotechnology in Agriculture and Forestry, vol 18. High-Tech and Micropropagation II. Springer, Berlin Heidelberg, New York. pp. 229-243.

Liu, J.R., K.C. Sink and Dennis, F.G. 1983. Adventive embryogenesis from leaf explants of apple seedlings. Hortscience. 18(6), 871-873.

Maheshwari, P., Kumar, A. 1998. Organogenesis, shoot regeneration and flowering response of Vernonia cinerea to different auxin/cytokinin combinations. In Vitro Cellular \& Developmental Biology. 42, 589-595.

Metivier, P.S.R., E.C. Yeung, K.R. Patel, Thorpe, T.A. 2007. In vitro rooting of microshoots of Cotinus coggygria Mill, a woody ornamental plant. In Vitro Cellular \& Developmental Biology. 43, 119-123.

Murashige, T. and Skoog F. 1962. A revised medium for rapid growth and bioassays with tobacco tissue culture. Physiologia Plantarun. 15, 473-497.

Nayak, P., P.R. Behera, Manikkannan, T. 2007. High frequency plantlet regeneration from cotyledonary node cultures of Aegle marmelos (L.) Corr. In Vitro Cellular \& Developmental Biology. 43, 231-236.

Ozean, S., M. Burghehi, S. Firek, Draper, J. 1992. High frequency adventitious shoot regeneration from Immature colyledons of Pea (Pisum sativum L.). Plant Cell Reports. 11, 44-47.

Razdan, M.K. 1993. An Introduction to Plant Tissue Culture. Oxford \& IEH Publishing Co. New Dehli.

Sabir, S.M. and Shah, A.S. 2004. Effect of chemical treatment, wax coating, oil dipping and storage behavior of apple (Malus domestica Borkh). Pakistan Journal of Nutrition. 3(2), 122-127.

Sharma, M., M. Modgil and Sharma, D.R. 2000. Successful propagation in vitro of apple rootstock MM106 and influence of phloroglucinol. Indian Journal of Experimental Biology. 38(12), 1236-1240.

Sreekumar, S., S. Seeni and Pushpangadan, P. 2000. Micropropagation of Hemidesmus indicus for cultivation and production of 2- hydroxy 4-methyl benzaldehyde. Plant Cell, Tissue and Organ Culture. 62, 211-218.

Zimmerman, R.H. 1991. Micropropagation of temperate zone fruit and nut crops. In: Debergh, P.C. and Zimmerman, R.H. (Ed.) Micropropagation. Dordrecht, Kluwer Academic Publishers, pp. 231-246.

\section{How to cite this article:}

Ravi Shekhar Kumar, Charu Joshi and Tapan Kumar Nailwal. 2016. Callus Induction and Plant Regeneration from Leaf Explants of Apple (Pyrus malus L.) cv. Golden Delicious. Int.J.Curr.Microbiol.App.Sci.5(2): 502-510. doi: http://dx.doi.org/10.20546/ijcmas.2016.502.057 